\title{
Alteration In Identity Of Talang Mamak Tribe
}

\author{
Ella Agustian, Sutinah \\ \{ ella.agustian-2017@pasca.unair.ac.id, tinafisip07@gmail.com \}
}

Universitas Airlangga, Surabaya, Indonesia

\begin{abstract}
Change is a natural state that constantly happens, whether it is rapidly or slowly. It also occurs to Talang Mamak tribe at Talang Jerinjing village. Their traditional characteristics are changing. They were a primitive traditional tribe, but now their characteristics have assimilated to migrants who brought modern identity and eliminate their original identity. This research aims to analyze the cause of this matter by using qualitative method approach. Generally, qualitative method is defined as naturalistic research because it is performed naturally and interviews are conduceted directly to the informants and the researcher is involved in social condition of Talang Mamak tribe. Talang Mamak tribe is located in Talang Jerinjing village area which is the forerunner of their growth. This research explains the reason why Talang Mamak tribe changed their identity by combining the theory by Petter L Berger and Thomas Luckmann. In their theory, there are three issues that can develop the alteration process, namely externalization that is carried by migrants as well as introduced through direct interaction; objectification that transforms their mindset; and internalization that reforms their culture.
\end{abstract}

Keywords: Identity Alteration, Talang Mamak, Social Construction

\section{Introduction}

Talang Mamak tribe in Talang Jerinjing village has the characteristics of traditional group alteration. Previously, this group was known as a primitive traditional group but currently they are undergoing identity assimilation with modern migrants. Tajfel stated that a personality will become a personality if the entire psychophysical system including expertise and characteristics of the activity is stated as a distinction in the adjustment to the environment. Individual personality, expertise, and characteristics will only be seen after one interacts with the environment [1]. Likewise, in Talang Mamak tribe, their original behavior began to fade along with the behavioral assimilation to immigrants.

The immigrants covered the original activities of Talang Jerinjing village residents, which is Talang Mamak tribe. Currently, people only recognize Malay tribe as the resident of Talang Jerinjing village. The urban population which is increasingly uncontrolled has affected Talang Mamak tribe. Consequently, their original identity or culture is shifted. Joseph Trimble said that ethnic identity is contextual and situational because generally it is caused by social negotiations of a person or group announcing a particular ethnic identity. If this identity is accepted by other people or groups, then it will differentiate them from other groups [1]

Talang Mamak tribe is an original group and a minority group in Talang Jerinjing village. Its status as a minority group of the Talang Mamak tribe requires them to accept the situation by assimilating and interacting directly to new groups. This identity establishment resulted in a new identity shared by the entire community of Talang Jerinjing village, regardless of the origin of the group. By these reasons, the researcher is interested in investigating identity alteration that occurred in Talang Mamak tribe. The emergence of identity similarity between Talang Mamak tribe and the immigrants is an interesting issue to be studied. Talang Mamak tribe accepts an identity alteration that continues to eliminate their original culture. 


\section{Literature Review}

The literature review is a review that explains the related references related to this research. In this literature review there are four related studies and serve as reference sources for research, due to the similarity of relationship characteristics both in concept and methodology. Some of these studies include the dissertation of $\mathrm{Fu} \mathrm{Xie}$, Thesis belonging to Yuandita Apriliani Siregar, research journal owned by Charles R Nangi, and Thesis belonging to Dhelmira Syafrini.

The dissertation belonged to Fu Xie from the University of Indonesia entitled Hubungan Antar Melayu-Bali dan Hubungan Agama Kristen Terhadap Agama Islam. The method in this study is quantitative which is considered interesting because there is rarely a study in sociology that uses quantitative methods. This research can provide an illustration of how identity construction can occur in different contexts so that unique characters emerge and create new identities [2]

This thesis of Yuandita Apriliani Siregar from the University of Indonesia entitled Diaspora India : Studi Tentang Etnisitas Identitas, Dan Jaringan Sosial, Komunitas Peranakan Muslim India di Kota. This thesis looks at a pattern that takes place in the community, especially in the Jakarta area and understands the identity and formation of existing networks. The advantages of this thesis explain the existence of a relationship of social relations that are formed so as to influence social identity that occurs in the existing social context. This thesis is comprehensive which is influenced by social networks [3]

This research journal owned by Charles R Nangi from the University of Indonesia, entitled Kontruksi Sosial dalam Realitas sosial di Kalangan Pedagang Kaki Lima, states that if an interaction occurs among the people, it always uses symbol symbols as a sign that is ingrained. This research journal provides a clear picture of the patterns of social relations that occur among groups, giving rise to new characteristics due to the mixing of traditions in each group [4]

The latest research is a Thesis belonging to Dhelmira Syafrini from Gajah Mada University entitled Cina dan Pembaurannya di Indonesia. This research is intended to find out what kind of model occurs in the integration of Chinese society in Indonesia. Dhelmira wrote in his literature study that there was a process of intermingling in Solo through total assimilation, such as religious conversion. The key to this research is the mixing process that gives rise to ethnic Chinese acceptance of the Solo community [5]

\section{Research Methodology}

Qualitative research approach was used for this research. In addition, the researcher went to the site and experienced directly the research object situation, but the presence of researcher did not significantly affect the dynamics of the research object. This is in line with the definition of qualitative research proposed by Sugiyono that qualitative research is a research method based on the philosophy of post-positivism which is used to examine objects in their natural condition and the researcher is the key instrument [6] To determine how the identity alteration process of Talang Mamak tribe as well as what factors affecting it, the researcher required in-depth data in order to simplify the data analysis and also clarifying the analysis results description. In qualitative research, primary data sources and data collection techniques allow the researcher to utilize direct observation, in-depth interview, and documentation techniques. The three data collection techniques were expected to be able to get more indepth, valid, reliable research data, and high level of data fairness, because researcher as the research instrument who collected data was in direct contact with the research subject and informants. 
This study uses purposive sampling, 10 informants were selected through the following criteria:

- Men / Women who are native descendants of the Talang Mamak Tribe.

- Men / Women who are immigrant communities living in the village of Talang Jerinjing.

- Influential people from two ethnic groups such as (indigenous leaders, village heads, and community leaders).

- The researcher used 10 informants from two sides, 5 informants from the Talang Mamak ethnic group and 5 informants from immigrant communities who settled in Talang Jerinjing village. This was done by the researcher as a comparison in getting relevant and logical research answers.

\section{Results and Discussion}

Talang Mamak tribe is the oldest tribe in Talang Jerinjing village. It is one of the Proto Malay units or Melayu Tuha. Consequently, this tribe is dominant in the history of Indragiri Hulu.

Talang Mamak tribe or Mamang Talang people use Malay language with their own dialect. The number of Proto Malay is decreasing in the Lancang Kuning Land. Therefore, the existence and name origin of Talang Mamak tribe is very well preserved in the history. Rab Tabrani stated in his book that "The name of the Talang Mamak tribe was taken from word "Talang" which in the old Malay means field, while Mamak is a call to a mother." This underlies their matrinialism background. Therefore, Talang Mamak has meaning of "mother's field". It characterizes the habit of Talang Mamak tribe for being a family group that utilizes nomadic farming method" [7]

\subsection{Identity Alteration Process of Talang Mamak Tribe}

Based on the theory by Petter L Berger and Thomas Luckmann, identity alteration is characterized by three stages, namely externalization, objectification, and internalization [8] The three existing processes will continue to run and are interrelated each other. So that in the process, everything will return to the internalization stage and so on until the individual establishes new meanings and behaviors if there are new values obtained.

\subsubsection{Extranalization Process}

The externalization process in Talang Mamak tribe is a form of assimilation effort to survive in the current condition of Talang Jerinjing village. Culture assimilation usually begins with interaction among groups, so that the interaction will affect assimilation of new cultures with previous values and norms as well as habit. As stated by Jamin:

"This is what we are, we are no longer keeping distance with new groups. We gather with the existing community. There is no special right that differentiates migrants and Talang Mamak tribe" (Jamin 15 December 2016).

Jamin's explanation is the first step of social interaction which indicates that Talang Mamak tribe is no longer closed to new groups in Talang Jerinjing village. In line with Jamin, Edi also said that currently "...there are many activities can be performed together, such as sports competitions or housewives' activities assimilating with Talang people" (Edi, December $16,2016)$. 
Currently, Talang Mamak tribe is able to follow the latest trends, Marlina for example, she said "...hehe huh, I rarely use mamak language. Children don't understand it either..." (Marlina interview, December 18, 2016). In addition, Sobarin realizes that Talang Mamak tribe has experienced many new things "...there is a various thing in this market, Talang tribe often shops in the market. They are no longer relying only on their plantation" (Sobarin, December 19, 2016).

Wati stated that currently she prefers to be a trader rather than farming. It is based on her needs. She prefers to be a trader because the current economic conditions are no longer the same as before, in which the forest was able to meet their needs. Today, education is implemented to their children so that they have to play a way to meet those needs (Wati, December 15, 2016).

Talang Mamak tribe basically has performed culture assimilation both unintentionally or intentionally. This can be seen by how they are performing their habit today, Arifin revealed that "education has become a significant matter for Talang Mamak tribe, you can see that they started attending school. Even it is far away in Rengat" (Arifin, December 17, 2016). Awareness of the importance of education has changed the mindset of Talang Mamak tribe. The factor that is not derived from Talang Mamak tribe began to affect their way of thinking.

The externalization process in Talang Mamak tribe is assimilation of ways of thinking and acting based on alteration in the activity. The activity was motivated by the economic transition procedures. Originally, agriculture was the most efficient in fulfilling daily needs, now it begins to change. The development of education and language assimilation make people stop using Talang Mamak terms and assimilating the language with Malay. In addition, the most striking alteration from the outside of Talang Mamak tribe is their lifestyle. Therefore, these matters are the most prominent external factors. The acceptance of new things is not obtained directly but it requires a new process to be internalized.

\subsubsection{Objectification Process}

Objectification is the result that has been achieved both mentally and physically from human externalization activities. The result is an objective reality that is separated from itself so that it has the potential to deal with, sometimes even controlling the producere in the realization [6]. For the second process, the objectification process in Talang Mamak tribe is marked by the existence of new cultures. The new cultures are able to dictate or regulate and change functions that have existed before, and they are unnoticed by Talang Mamak tribe. As revealed by the village head of Talang Jerinjing, Edi Santoso, he stated that: “...Talang people are now living a luxurious life, unlike back in the days when they were still living in the forest. As you can see, their appearance and cellphone are also sophisticated..." (Edi, December 16, 2016). Edi's statement is inseparable from the existing reality. It is marked directly by the inner attitude of Jamin who have used a cellphone as an important tool in communicating. On the other hand, Arifin who is a teacher at Vocational High School of West Rengat in the Talang Jerinjing village area stated “...in my opinion, these Talang kids do not fully understand. Yes, it is normal for teenagers being curious about new things related to technology. I ever caught some Talang students watching movies in the school toilet during school hours..." (Arifin, December 17, 2016).

Sobarin added that currently he has seen if Talang Mamak tribe is similar to the others, it is a form of an almost perfect identity assimilation. In addition, he also said that Talang Mamak tribe is basically smart and easy to understand something. It is based on the number of Talang people who have TV, almost every household of Talang Mamak tribe has TV "...hahaha, Talang people do not need to be taught, they learn from TV directly..." (Sobarin, December 19, 2016). This is in line with Inayah, an employee in Talang Jerinjing village hall, who stated that if when the village hall is closed, the teenagers from Talang Mamak tribe are going to the hall 
to use the $\mathrm{Wi}-\mathrm{Fi}$ "....in the afternoon, there will be a lot of teenagers in the village hall fixing their eyes on their cellphones. They consist of both local children and Talang children," (Inayah, December 19, 2016).

Apart from technological matters, objectification also recruits the economy as an object that focuses on the transition of the previous livelihood system of Mamak Talang tribe. Alteration in the work system adopted by Talang Mamak tribe affects the family income. Edi stated that palm oil mills in Talang Jerinjing village recruit skilled young men to work as laborers or employees, such as in the following statement "...currently, the factory is pretty much recruiting village teenagers. In addition, the laborers or employees are mostly Talang people that has begun to choose to work" (Edi, December 16, 2016).

Talang Mamak tribe was known as a reliable farmer in growing crops for their daily needs, but now they have turned into factory employees who have a certain income. The external effects seem to be an important part of this alteration. Erviana stated that it is not only Talang Mamak tribe men but also women who began to work in order to support the family economy. (Erviana, December 17, 2016).

Inayah, as a village employee stated that "... as I remember, there are only few hectares of land which is used as a nomadic plantation area because most of the land is certified" (Inayah, December 19, 2016). Due to the limited area for nomadic plantation, they change the plantation system. They only plant crops that have a fast harvest period.

The generation of each group will always have an alteration of attitude and mindset, Talang Mamak tribe as an indigenous group that was known for its resistance, now it is not. Talang Mamak tribe can receive modern things from any aspect, including education. Education is an important foundation in the development of mindset among individuals and groups.

It proves that Talang Mamak tribe is no longer a primitive group which is easy to be exploited both in terms of thought or behavior. It is convincing that Talang Mamak tribe can accept developments easily, including in terms of education. Inayah stated that "they are diligent now; the Elementary School Equivalency Test yesterday was participated by nearly 30 people..." (Inayah, December 19, 2016).

\subsubsection{Internalization Process}

At this stage, individuals will absorb all things which are objective and then it will be realized subjectively. This internalization lasts a lifetime through socialization. In the internalization process, each individual varies in terms of absorption. Some absorb the external aspects more, and some others absorb the internal aspects more. In addition, the internalization process can be acquired by individuals through the primary and secondary socialization processes. The internalization process that has occurred in Talang Mamak tribe is marked by the following changes:

Table 1: internalization of new culture of Talang Mamak tribe

\begin{tabular}{lll}
\hline Aspects & Old Identity & New Identity \\
\hline Lifestyle & - black teeth due to menyirih & - modern fashion \\
& (chewing betel leaf), long & - using electronic \\
& hair, and wearing "loincloth" & communication \\
& for men and long fabrics for & tools. \\
& women & \\
& - communication by direct & \\
interaction & \\
Economy & - Only relying on the & - various types of \\
& agricultural system & work
\end{tabular}




\begin{tabular}{|c|c|c|}
\hline & - barter transaction & $\begin{array}{l}\text { Not using barter } \\
\text { system. }\end{array}$ \\
\hline Education & $\begin{array}{l}\text { - Only implementing the } \\
\text { custom system as the basis of } \\
\text { their action } \\
\text { - Illiterate } \\
\text { - Melayu Tuha language }\end{array}$ & $\begin{array}{l}\text { Modern formal } \\
\text { education } \\
\text { Get to know } \\
\text { characters and } \\
\text { numbers } \\
\text { Modern Malay and } \\
\text { bahasa }\end{array}$ \\
\hline
\end{tabular}

The table 1 occur due to the acceptance of new cultures which are affected by external factors. The existing externalization processes are affected by economy, education, lifestyle and language factors. Therefore, the objectified social reality begins to replace the existing values and norms unconsciously and comprehensively. The occurred social reality is a new form, so that Talang Mamak tribe people will absorb it in a comfortable manner and slowly replace the previous culture.

\section{Conclusion}

The change identity is inseparable from the three processes that support this alteration, namely Externalization which is the inclusion of a thought based on alterations in lifestyle, economy, education, and language resulting in new thought and starting to change the previous mindset. The process is marked by objectification of a situation in which the advanced process of externalization is supported by legitimate institutions. In addition, the objectification process is a process that faces each other between the users and the existing processes, without realizing that at this stage the user is a creature driven by the plot. The final stage is marked by internalization, in which all the affects that have included become a new habit. The habit is undeniable that it will continue to repeat in the next generation or even replaced by a new culture. Therefore, this last stage creates identity assimilation that is no longer the same as before. It is created as a form of cultural transition to survive and maintain the existence of the new version of Talang Mamak tribe.

\section{References}

[1] j. Trimble and R. Dickson, Ethnik Identity, Woshington: Western Woshington University, 2010.

[2] F. Xie, "Hubungan antar orang kristen dan muslim dalam masyarakat sipil, hubungan antar MelayuBali dan Hubungan agama hindu dan islam," in Thesis, Jakarta, program pascasarjana Universitas Indonesia, 2006.

[3] A. Y. Siregar, "Diaspora India : Studi tentang etnisitas Identitas, dan jaringan sosial, komunitas peranakan muslim India di Kota," in Thesis, Jakarta, Program Pascasarjana Universitas Indonesia, 2011.

[4] C. R. Nangi, "kontruksi sosial dalam realitas sosial dikalangan pedagang kaki lima," Repositori Universitas Indonesia, vol. 07, 2011.

[5] D. Syafrini, "Etnis Cina dan pembaurannya di Indonesia," yogyakarta, program pascasarjana universitas gajah mada, 2014.

[6] Sugiyono, "metode penelitian kualitatif, kuantitatif, R\&D," Bandung, Alfabeta, 2009.

[7] T. Rab, "Lancang kuningku," Pekanbaru, Lembaga Keadatan Melayu Riau, 2016.

[8] P. Berger and T. Lucmann, "The social contruction of reality: A Treatise its the soiciology of 
knowladge," New York, Anchor Book, 1990. 